\title{
PEDAGOGICAL MODEL FOR THE DEVELOPMENT OF A SUSTAINABLE LIFESTYLE OF A STUDENT IN A CULTURAL LANDSCAPE
}

\author{
MODELO PEDAGÓGICO PARA O DESENVOLVIMENTO DE UM ESTILO DE \\ VIDA SUSTENTÁVEL DE UM ESTUDANTE EM UMA PAISAGEM CULTURAL
}

\author{
MODELO PEDAGÓGICO PARA EL DESARROLLO DE UN ESTILO DE VIDA \\ SOSTENIBLE DE UN ESTUDIANTE EN UN PAISAJE CULTURAL
}

\author{
Natalia Nikolaevna DEMIDOVA ${ }^{1}$ \\ Anna Aleksandrovna LOSHCHILOVA ${ }^{2}$ \\ Natalya Fedorovna VINOKUROVA ${ }^{3}$ \\ Anastasia Vasilievna ZULKHARNAEVA ${ }^{4}$ \\ Natalia Viktorovna MARTILOVA ${ }^{5}$
}

\begin{abstract}
The article considers the eco-friendly lifestyle of a person in a cultural landscape as a prerequisite for sustainable development of a territory and a practical basis for creating a qualitatively new harmonious interaction between society and natural systems. The goal of the article is to theoretically substantiate, devise, and test a pedagogical model that would teach students a sustainable lifestyle in a cultural landscape. The methodological basis of the study is the coevolutionary subjective, activity, transdisciplinary, integral, situational, cultural, ecological, landscape, and environmental approaches, as well as some principles embodying them. Educational modeling and design were the key theoretical methods. The pedagogical model created combines the target, substantive, procedural, technological, productive, and evaluative components. Its practical use in schools proved to be effective regarding the formation of an ecofriendly lifestyle of students in the cultural landscape.
\end{abstract}

KEYWORDS: Culture of nature management. Cultural landscape. Sustainable lifestyle.

${ }^{1}$ Minin Nizhny Novgorod State Pedagogical University (MININUNIVER), Nizhny Novgorod - Russia. Professor of the Department of Environmental Education and Rational Nature Management. Doctor of Pedagogical Sciences. ORCID: https://orcid.org/0000-0003-3536-7382. E-mail: nn_demidova@inbox.ru

${ }^{2}$ Minin Nizhny Novgorod State Pedagogical University (MININUNIVER), Nizhny Novgorod - Russia. Associate Professor of the Geography Department of General and Social Pedagogy. Candidate of Pedagogical Sciences. ORCID: https://orcid.org/0000-0002-6296-5516. E-mail: annaloschilova@bk.ru

${ }^{3}$ Minin Nizhny Novgorod State Pedagogical University (MININUNIVER), Nizhny Novgorod - Russia. Professor the Geography, Geoecology Education and Geography Education Department. Doctor of Pedagogical Sciences. ORCID: https://orcid.org/0000-0002-2673-7700. E-mail: nfvinokurova@mail.ru

${ }^{4}$ Minin Nizhny Novgorod State Pedagogical University (MININUNIVER), Nizhny Novgorod - Russia. Associate Professor of the Geography, Geoecology Education and Geography Education Department. Candidate of Pedagogical Sciences. ORCID: https://orcid.org/0000-0003-2210-8648. E-mail: anastasia.zulkharnaeva@yandex.ru

${ }^{5}$ Minin Nizhny Novgorod State Pedagogical University (MININUNIVER), Nizhny Novgorod - Russia. Associate Professor of the Department of Geography, Geographical and Geoecological Education. Candidate of Pedagogical Sciences. ORCID: https://orcid.org/0000-0002-8118-5195. E-mail: natalyamartilova@list.ru

RPGE- Revista on line de Política e Gestão Educacional, Araraquara, v. 25, n. 3, p. 2291-2310, Sep./Dec. 2021. e-ISSN: 1519-9029 
RESUMO: $O$ artigo considera o estilo de vida ecológico de uma pessoa em uma paisagem cultural como um pré-requisito para o desenvolvimento sustentável de um território e uma base prática para criar uma interação nova harmoniosa qualitativamente entre a sociedade e os sistemas naturais. $O$ objetivo do artigo é teoricamente fundamentar, conceber e testar um modelo pedagógico que ensine aos estudantes um estilo de vida sustentável em uma paisagem cultural. A base metodológica do estudo é a abordagem subjetiva, atividade transdisciplinar, integral, situacional, cultural, ecológica, paisagística e ambiental coevolucionária, assim como alguns principios que as incorporam. A modelagem educacional e o design foram os principais métodos teóricos. O modelo pedagógico criado combina os componentes-alvo, substantivos, processuais, tecnológicos, produtivos e avaliativos. Seu uso prático nas escolas provou ser eficaz no que diz respeito à formação de um estilo de vida ecologicamente correto dos estudantes na paisagem cultural.

PALAVRAS-CHAVE: Cultura de gestão da natureza. Paisagem cultural. Estilo de vida sustentável.

RESUMEN: El artículo considera el estilo de vida ecológico de una persona en un paisaje cultural como un requisito previo para el desarrollo sostenible de un territorio y una base práctica para crear una interacción armoniosa cualitativamente nueva entre la sociedad y los sistemas naturales. El objetivo del artículo es fundamentar, diseñar y probar teóricamente un modelo pedagógico que les enseñaría un estilo de vida sostenible en un paisaje cultural. La base metodológica del estudio son los enfoques coevolutivos subjetivo, de actividad, transdisciplinar, integral, situacional, cultural, ecológico, paisajístico y ambiental, así como algunos principios que los incorporan. El modelado y el diseño educativos fueron los métodos teóricos clave. El modelo pedagógico creado combina los componentes objetivo, sustantivo, procedimental, tecnológico, productivo y evaluativo. Su uso práctico en las escuelas demostró ser eficaz en la formación de un estilo de vida ecológico de los estudiantes en el panorama cultural.

PALABRAS CLAVE: Gestión de la cultura de la naturaleza. Paisaje cultural. Estilo de vida sostenible.

\section{Introduction}

Intense transformation of modern landscapes and inefficient use of their natural resources exceed the ecological capacity of the territory and undermine its sustainability. By destroying the natural environment, humanity threatens its environmental safety. According to Moiseev (1999), the human has come to the line that cannot be crossed under any circumstances. One careless step and humanity will fall into the abyss. One rash movement and Homo sapiens as the biological species may disappear from the face of the Earth. The reasons for the current crisis lie in the values and cultural attitudes of the individual and, consequently, how we live in the environment. 
The 2030 Agenda for Sustainable Development (UNITED NATIONS, 2015), the Incheon Declaration, the Education 2030: Framework for Action (UNESCO, 2016), and The Hangzhou Declaration (UNESCO, 2013) claim that global education should shift its focus towards the formation of a new culture that ensures sustainable and safe future. The Hangzhou Declaration notes that culture is becoming a key catalyst for sustainability, a source giving meaning, energy, creativity, innovation, as well as tools to understand tasks and find appropriate solutions, and people should form a new culture in order to overcome the systemic crisis.

Some researchers (CONCINA, 2019; KOCHHAR-LINDGREN, 2015; SÁNCHEZ GALERA, 2020; VAN GROENOU, 2005) examined the aspects of this new culture as a way of adjusting and organizing human life in new conditions. Here, we would like to talk about the culture of nature management, which we consider as the culture of post-industrial society that reflects the development of applied directions of post-nonclassical science and is based on the coevolutionary system of values, and the creative and constructive activity (CONCINA, 2019; EFFENDI, 2019). Representing a specific way of human life, we define the culture of nature management as a method, measure, result of cognition, assessment, and activities aimed at sustainable cultural development of territories at various levels by a human (KOCHHARLINDGREN, 2015; STENGERS, 2017).

In line with this approach, we perceive it relevant to promote sustainable lifestyle among people living in the social and natural environment, and above all, among schoolchildren.

In this research, we highlighted the unique role of cultural landscapes in the development of eco-friendly lifestyle of adolescents. The cultural landscape represents the synthesis, fusion of material and spiritual values of different eras, and culture-congruent interaction between human and nature. Its complex nature of interconnections physically embodies the idea of cocreation of human and nature and represents an example of an ecofriendly lifestyle of modern people.

Having analyzed international and Russian studies (KAGANSKY, 2009; RAGULINA, 2015; TRESS; TRESS; FRY, 2005; VEDENIN, 2019; ZAMYATIN, 2008), we identified that educators do not fully use the potential of cultural landscapes, which hinders the performance of its teaching and educational function (RAGULINA, 2015).

Therefore, it is necessary to develop and implement a new life and value pedagogical model promoting an eco-friendly lifestyle of an individual in a cultural landscape. This would transform adolescents from outside observers and spectators into real actors of the coevolutionary process, who can build their relationships with the environment on the basis of partnership, tolerance, and responsibility. This pedagogical model implies a conjugate, 
interdependent change in human qualities and characteristics of the surrounding landscape aimed at sustainable codevelopment and higher standard of living. New eco-friendly ideas give an impulse for the practical implementation of fundamentally new development priorities based on the principles of the advanced development of educational systems.

Theoretical and methodological outcomes of solving this problem will demonstrate students how their lifestyle may fit into the cultural landscape. They will also see the interdependence of its condition, the quality of life, and their ability to design and implement sustainable activities and flexibly respond to environmental challenges. All this determines the relevance and scientific significance of this study.

\section{Materials and Methods}

Students acquire the ideas of sustainable lifestyle in a cultural landscape by doing projects that enable them to comprehend cultural and ecological realities of the environment in the context of coevolution and sustainable development. The theoretical and methodological basis of the study was coevolutionary subject-activity, transdisciplinary, integral, situationalintegral, cultural-ecological, and landscape-environmental methodological approaches.

The coevolutionary subject-activity approach (VINOKUROVA et al., 2021) reflects V. I. Vernadsky's worldview ideas of the noosphere and coevolution (MOISEEV, 1999) as the coexistence of a person with a cultural landscape based on logical, moral, ethical, and aesthetic interaction (DEMIDOVA et al., 2021; LOSHCHILOVA et al., 2019, 2020; MOISEEV, 1999).

The transdisciplinary approach to create a pedagogical model for the development of a sustainable lifestyle in a cultural landscape implies the synthesis of various forms of understanding the world (philosophy, science, art, etc.). It incorporates the ideas of integrity (holism), integration, and self-organization (synergetics). We believe that the interaction of the individual with the cultural landscape is initially transdisciplinary, since the cultural landscape can be studied with both mind and heart, using various means of cultural comprehension of the reality and methods of cognition (rational, irrational, situational, or enactivated cognition (MATURANA; VARELA, 1980).

The cultural-ecological approach uses green initiatives and the cultural paradigm of modern education. Regarding its genesis, we may define the cultural-ecological approach as the eco-design of applied landscape studies in the context of cultural ideas. Thus, we considered the cultural landscape as a continuation of culture, where the components of the cultural landscape act as values that have become part of a person's life. 
The implementation of the cultural-ecological approach in education qualitatively affects all components of the pedagogical model for the development of sustainable lifestyle, directing them towards achieving the strategic goal — the culture of environmental management.

The landscape-environmental approach develops the ideas of the cultural-ecological approach. The comprehension of the cultural landscape within the sustainable lifestyle of a person belongs to open human-sized systems, in which a person exists as part of the cultural landscape. A person naturally lives in a landscape, and their life outside the landscape is inconceivable (PREOBRAZHENSKY, 2001). What is more, the landscape expresses itself through a person who is a landscape creature (HEIDEGGER, 1971).

The integral approach of Wilber (2007) assumes the integral perception of the world and the cognizing subject in it. Therefore, the pedagogical model for the development of a sustainable lifestyle in a cultural landscape sees the individual and their activities as part of a complex integral socionatural system embracing the environment, society, and culture and reflecting its systemic qualities.

The operating system of the integral approach is the AQAL model (All Quadrants, All Levels), which gives a holistic picture of jointly developing processes and allows studying the internal and external aspects of any phenomenon. This integral model includes four dimensions (quadrants), levels, lines, and types, which are the elements of cognition. Quadrants represent the horizontal vector of the integral model: quadrant 1 is "I" (internally individual, intentional), quadrant 2 is "We" (internally collective, cultural), quadrant 3 is "It" (externally individual, behavioral), and quadrant 4 is "They" (externally collective, social). Ragulina (2015) developed this approach from the perspective of the cultural landscape. She presented the content of the cultural landscape through all its constituent elements (culture, personality, society, and nature) and examined their evolution, mutual influence, and role in this process.

The situational-integral approach complements the provisions of the integral approach in the field of teacher training. A significant element of this approach is the ideas of situationality and enactivation of cognition (ROCHA et al., 2017). They consider the cognizing subject through the interaction with the world, in dialogue with it, in structural connection with the systems of the environment. The integral-situational approach demonstrates how to develop a sustainable lifestyle of the individual by studying cultural landscapes using various integral situations with a focus on culture. Such situations reflect the idea of the continuity of the cultural development of the landscape, from adaptation through comprehension to constructive and creative activity. Here, we identified three types of integral situations: cultural adaptive, cultural semantic, and cultural activity. 
To test the effectiveness of the pedagogical model for developing methods of students' sustainable lifestyle in a cultural landscape, we devised a diagnostic methodology called "Integral Project: A Journey Through the Cultural Landscape" (VINOKUROVA et al., 2021).

The theoretical and methodological foundations of this method were the provisions of the integral-situational approach and the theoretical aspects of the subject-subject type of Panov's (2015) eco-psychological interaction. We applied this method to determine the level of students' sustainable lifestyle. For this, we used an integral project, which included three subprojects, successively interconnected with each other. Each of the subprojects included various aspects of the subject-subject interaction of the individual and the cultural landscape, as well as particular methods for developing the sustainable lifestyle of a person in the cultural landscape.

Level 1: Subproject "I and the Cultural Landscape" identifies the method of sustainable life perception, in which the student and the cultural landscape interact as independent actors.

Level 2: Subproject "I am in the Cultural Landscape" evaluates the method of sustainable life comprehension, which implies active collaborative interaction of students and the cultural landscape.

Level 3: Subproject "Together with the Cultural Landscape" demonstrates the readiness for a sustainable lifestyle design based on the subject-generating interaction of the person and the cultural landscape.

Each subproject contains four tasks that reflect the sectors of the integral model of the sustainable lifestyle (Table 1). In total, there are 12 tasks, which confirms the functional completeness of the diagnostics. Three types of situations considered in the table determine the content of subprojects and their integrity.

Table 1 - Integral diagnostic map of a sustainable lifestyle

\begin{tabular}{|c|c|c|c|c|c|}
\hline \multicolumn{2}{|c|}{$\begin{array}{l}\text { Level 1. Subproject "I and the } \\
\text { Cultural Landscape" }\end{array}$} & \multicolumn{2}{|c|}{$\begin{array}{l}\text { Level 2. Subproject "I am in the } \\
\text { Cultural Landscape" }\end{array}$} & \multicolumn{2}{|c|}{$\begin{array}{l}\text { Level 3. Subproject "Together } \\
\text { with the Cultural Landscape" }\end{array}$} \\
\hline \multicolumn{2}{|c|}{ Integral model of life perception } & \multicolumn{2}{|c|}{$\begin{array}{l}\text { Integral model of life } \\
\text { comprehension }\end{array}$} & \multicolumn{2}{|c|}{ Integral model of life design } \\
\hline $\begin{array}{l}\text { 1.1. Image } \\
\text { ontological } \\
\text { perception }\end{array}$ & $\begin{array}{l}\text { 1.4. Needs and } \\
\text { expressive } \\
\text { creativity }\end{array}$ & $\begin{array}{l}\text { 2.1. Image } \\
\text { meaning attitude }\end{array}$ & $\begin{array}{c}2.4 . \\
\text { Stimulative } \\
\text { productive } \\
\text { creativity }\end{array}$ & $\begin{array}{l}\text { 3.1. Image } \\
\text { cocreative }\end{array}$ & $\begin{array}{l}\text { 3.4. Innovative } \\
\text { cocreativity }\end{array}$ \\
\hline $\begin{array}{l}\text { 1.2. Meaning- } \\
\text { making }\end{array}$ & $\begin{array}{c}1.3 . \\
\text { Identification }\end{array}$ & $\begin{array}{l}\text { 2.2. Meaning- } \\
\text { comprehension }\end{array}$ & $\begin{array}{l}\text { 2.3. Self- } \\
\text { identification }\end{array}$ & $\begin{array}{l}\text { 3.2. Meaning- } \\
\text { creation }\end{array}$ & $\begin{array}{l}\text { 3.3. Self- } \\
\text { realization }\end{array}$ \\
\hline \multicolumn{6}{|c|}{ Problem focus of subprojects } \\
\hline \multicolumn{2}{|c|}{$\begin{array}{l}\text { Cultural and adaptive integral } \\
\text { situation }\end{array}$} & \multicolumn{2}{|c|}{$\begin{array}{l}\text { Cultural and semantic integral } \\
\text { situation }\end{array}$} & \multicolumn{2}{|c|}{$\begin{array}{l}\text { Cultural and creative integral } \\
\text { situation }\end{array}$} \\
\hline
\end{tabular}

Source: Prepared by the authors 
The number of completed tasks within a subproject demonstrates how well a certain method of sustainable lifestyle was formed. We carried out subprojects gradually since the previous project formed the basis for the next one. The person who did all tasks of Level 1 Subproject could proceed to the second level. This is due to the development specifics of the methods of the sustainable lifestyle: without perception, there is no comprehension, while comprehension is a prerequisite for eco-friendly creative activity.

At first, we instructed the students. To work on an integral project, they had to choose a cultural landscape that was significant for them. Next, following the traveler's navigator, they were to solve a number of problems and record them in the travel diary (the answer form).

We assessed how well the tasks were completed using the Integrated Project Assessment Card (Table 2), which included tasks, criteria for their solution, and performance indicators ("completed" -2 points, "partially completed" - 1 point, and "not completed" -0 points).

We summed up the points obtained for solving problems in each project. Since the students did the projects successively, the points for the latest project and the sum of the points of the previous ones were totaled (cumulative assessment system). We assessed the project of the next level only after students completed all tasks of the previous project. The threshold level for passing Level 1 was 8 points, Level 2 - 16 points, and Level 3 - 24 points. Table 2 contains the interpretation of the results.

Table 2 - Results interpretation

\begin{tabular}{|l|l|l|}
\hline $\begin{array}{l}\text { Level 1. Subproject "I and the } \\
\text { Cultural Landscape": The } \\
\text { evaluation of sustainable life } \\
\text { perception }\end{array}$ & $\begin{array}{l}\text { Level 2. Subproject "I am in the } \\
\text { Cultural Landscape": Evaluation } \\
\text { of sustainable life comprehension }\end{array}$ & $\begin{array}{l}\text { Level 3. Subproject "Together } \\
\text { with the Cultural Landscape": } \\
\text { Evaluation of sustainable } \\
\text { lifestyle design }\end{array}$ \\
\hline $0-3$ points - low level & $8-11$ points - low level & $16-19$ points - low level \\
\hline $4-7$ points - medium level & $12-15$ points - medium level & $20-23$ points - medium level \\
\hline $\begin{array}{l}\text { 8 points - full mastery of } \\
\text { sustainable life perception }\end{array}$ & $\begin{array}{l}16 \text { points - full mastery of } \\
\text { sustainable life comprehension }\end{array}$ & $\begin{array}{l}24 \text { points }- \text { full mastery of } \\
\text { sustainable life creation }\end{array}$ \\
\hline
\end{tabular}

Source: Prepared by the authors

We evaluated the effectiveness of the pedagogical model for the development of a sustainable lifestyle of a student in a cultural landscape using the diagnostic method "Integral Project: A Journey Through the Cultural Landscape" on experimental sites in schools in the city of Nizhny Novgorod and the Nizhny Novgorod region (Russia). The experiment involved 512 school students aged 14-15, and we carried it out in the period from 2019 to 2021. 


\section{Results}

We built the pedagogical model for the development of students' sustainable lifestyle in a cultural landscape according to the approaches and principles considered in the previous section. The structure of this model included interrelated goal, content, procedural, technological, productive and evaluative, as well as diagnostic components (Table 3 ).

Table 3 - Pedagogical model for the development of sustainable lifestyle of students in a cultural landscape

\begin{tabular}{|c|c|c|c|c|c|c|}
\hline \multicolumn{3}{|c|}{ Goal component } & \multirow{3}{*}{$\begin{array}{l}\text { Content } \\
\text { component }\end{array}$} & \multirow{3}{*}{$\begin{array}{c}\text { Technological } \\
\text { component }\end{array}$} & \multirow{3}{*}{$\begin{array}{l}\text { Productive } \\
\text { and } \\
\text { evaluative } \\
\text { component }\end{array}$} & \multirow{3}{*}{$\begin{array}{l}\text { Diagnostic } \\
\text { component }\end{array}$} \\
\hline $\begin{array}{c}\text { Strategic } \\
\text { goal }\end{array}$ & Goal & Subject & & & & \\
\hline $\begin{array}{l}\text { Formation } \\
\text { of the nature } \\
\text { management } \\
\text { culture }\end{array}$ & $\begin{array}{l}\text { Ways of } \\
\text { sustainable } \\
\text { lifestyle }\end{array}$ & $\begin{array}{l}\text { Integration of } \\
\text { a person into } \\
\text { the cultural } \\
\text { landscape }\end{array}$ & & & & \\
\hline $\begin{array}{l}\text { Cultural and } \\
\text { creative } \\
\text { stage }\end{array}$ & $\begin{array}{c}\text { Life creation } \\
\text { (creativity in } \\
\text { the cultural } \\
\text { landscape) }\end{array}$ & $\begin{array}{l}\text { Generating } \\
\text { subject } \\
\text { Self- } \\
\text { realization }\end{array}$ & $\begin{array}{c}\text { Praxeolo } \\
\text { gical } \\
\text { compone } \\
\mathrm{nt}\end{array}$ & $\begin{array}{l}\text { Cultural and } \\
\text { creative } \\
\text { integral } \\
\text { situation }\end{array}$ & $\begin{array}{l}\text { Cultural and } \\
\text { creative } \\
\text { level } \\
\text { Subject- } \\
\text { generative } \\
\text { type of } \\
\text { interaction }\end{array}$ & $\begin{array}{l}\text { Integral } \\
\text { project } \\
\text { "Together } \\
\text { with the } \\
\text { cultural } \\
\text { landscape" }\end{array}$ \\
\hline $\begin{array}{l}\text { Cultural and } \\
\text { meaning } \\
\text { stage }\end{array}$ & $\begin{array}{c}\text { Life } \\
\text { comprehensio } \\
n \\
\text { (comprehendi } \\
\text { ng the cultural } \\
\text { landscape) }\end{array}$ & $\begin{array}{l}\text { Cooperating } \\
\text { subject } \\
\text { Self- } \\
\text { determination }\end{array}$ & $\begin{array}{c}\text { Cognitiv } \\
\mathrm{e} \\
\text { compone } \\
\mathrm{nt}\end{array}$ & $\begin{array}{c}\text { Cultural and } \\
\text { content } \\
\text { integral } \\
\text { situation }\end{array}$ & $\begin{array}{c}\text { Cultural and } \\
\text { content level } \\
\text { Subject- } \\
\text { collaborative } \\
\text { type of } \\
\text { interaction } \\
\end{array}$ & $\begin{array}{c}\text { Integral } \\
\text { project } \\
\text { "I am in the } \\
\text { cultural } \\
\text { landscape" }\end{array}$ \\
\hline $\begin{array}{l}\text { Cultural and } \\
\text { adaptation } \\
\text { stage }\end{array}$ & $\begin{array}{c}\text { Life } \\
\text { perception } \\
\text { (adaptation in } \\
\text { the cultural } \\
\text { landscape) }\end{array}$ & $\begin{array}{c}\text { Isolated } \\
\text { subject } \\
\text { Self- } \\
\text { identification }\end{array}$ & $\begin{array}{c}\text { Emotion } \\
\text { al and } \\
\text { figurativ } \\
\mathrm{e} \\
\text { compone } \\
\text { nt }\end{array}$ & $\begin{array}{l}\text { Cultural and } \\
\text { adaptive } \\
\text { integral } \\
\text { situation }\end{array}$ & $\begin{array}{l}\text { Cultural and } \\
\text { adaptive } \\
\text { level } \\
\text { Subject- } \\
\text { isolated type } \\
\text { of } \\
\text { interaction }\end{array}$ & $\begin{array}{c}\text { Integral } \\
\text { project } \\
\text { "I and the } \\
\text { cultural } \\
\text { landscape" }\end{array}$ \\
\hline
\end{tabular}

Source: Prepared by the authors

The goal component of the model embraces strategic and subject goals. The culture of environmental management acts as a strategic goal, and we considered it as a method, measure, result of cognition, assessment, and activities aimed at the cultural development of territories of various scales by human for their sustainable development (LOSHCHILOVA et al., 2019, 2020).

The subject goal implies that the student becomes a subject through the development of sustainable lifestyle in a cultural landscape. 
The dynamics of a particular lifestyle metaphorically reflects the semantic series "I feel - I think - I act" (BRANDIST; TIHANOV, 2000) as a person is mastering the value and semantic dominants of the cultural landscape:

1. Through adaptation in a multidimensional and varied cultural landscape: perception of life;

2. Comprehension of the co-evolutionary values of the cultural landscape: life comprehension;

3. Their exteriorization as a result of cocreative transformation: creativity in the cultural landscape (life creation).

When identifying lifestyles in the cultural landscape and forming student's personality as its subject, we relied on the ideas about the development of equitable relationships between the person and the environment. We linked life perception with the formation of an isolated subject, life comprehension-a cooperating subject, and life creation reflects the formation of a generating subject.

The content component of the model has two elements based on the ideas of Khutorskoy (2021). When constructing it, we focused on the internal increments and personality development. Internal content is an attribute of the personality, the external content assimilated by the individual.

The external content is interdisciplinary and studies cultural landscapes as integral human-sized systems. Human-sized systems reflect a new type of rationality and embrace a whole range of possibilities for the person's life in line with the culture of nature management. The latter implies adaptation, revision of meanings, and ecological creativity. Therefore, the following components manifest themselves in the external content:

1) The emotional and image component reflects the image knowledge. It provides experience and emotional perception of the cultural landscape through images that are part of the sensual representations of the student and take the form of cultural symbols and signs. Their subsequent denotation implies that the personality becomes part of the cultural landscape.

2) The cognitive component manifests itself in scientific knowledge about the cultural landscape as a complex self-developing system consisting of components that interact with each other. The conceptual and terminological core of the component contains the following concepts: 
a) The cultural landscape, the essence, and the specifics of processes required for maintaining the stability of the cultural landscape and human involvement in these processes;

b) Coevolutionary interactions as interactions of heterogeneous natural and cultural formations of the cultural landscape;

c) An integral sustainable situation resulting from the interaction in the system "Human-Cultural Landscape-Culture of Nature Management";

d) Sustainable development of the cultural landscape - a controlled process of the development of social and natural systems.

3) The value and normative component is contextually presented at all content levels. It allows the individual to enter the world of coevolutionary values and determines the formation of students' personal values. The component unites categories that define various value and normative aspects of the culture of nature management. It includes a system of values and norms underlying a harmonious relationship between a person and the cultural landscape in the past, present, and future. These are historically established ecological traditions (sustainable rituals, customs, ceremonies, folklore, mythology, and place names) and modern environmental ethics with the focus on sustainable development (setting quotas for nature management, equality of ecological spaces, and legislative acts regulating nature management).

4) The content of the praxeological component implements the constructive and ecological ideas of optimization, humanization, and harmonization of students' interaction with the cultural landscape according to the nature management culture. The content includes sustainable activities: adaptive, transformative, constructive, and creative.

The transition of the external content into the internal one involves the formation of the personality as a subject of sustainable lifestyle through such subsequent stages as selfidentification, self-determination, and self-realization.

When developing the content component, the crucial element was its algorithmization, structuring based on the integral approach of Wilber (2007), the concept of system differentiation by Chuprikova (2009), Karopa (1999) and morphological and functional integration (VINOKUROVA et al., 2021). 
The structure, the algorithm for studying the content includes the following blocks: 1) a holistic image content block representing emotional and image content; 2) a differential and theoretical content block with cognitive and semantic content; 3) a holistic and constructive content block with creative and practical content.

Cultural integral situations represent the content of these blocks. Their features are considered below in the technological component.

The procedural component of the pedagogical model reflects the process of mastering the value and semantic dominants of the cultural landscape by the individual. We identified the following stages:

1) The cultural adaptation stage involves the formation of the person's lifestyle through experiencing and determining meanings. At this stage, sensations become the sensory support for denotation when the person integrates into the cultural landscape.

2) The cultural and semantic stage ensures the awareness and comprehension of the cultural landscape.

3) In the context of the nature management culture, the cultural creative stage reflects the creative activity of the individual aimed at the sustainable development of the cultural landscape in line with the values that have acquired the personal meaning at the cultural and semantic level. The person evaluates their activities in accordance with new personal meanings and forms a new strategy of cocreative interaction with nature.

We identified and substantiated the technology of creating integral situations with a cultural focus, the core of which are the situations that motivate the student to apply eco-friendly methods of life perception, life comprehension, and life creation.

In the context of enactivated cognition, they represent a process structure that reflects the continuity of the cultural development of the landscape: from adaptation and comprehension to constructive and creative activity. Here, we identified the following types of integral situations. Cultural adaptive integral situation allows students to master the methods of ecofriendly life perception of the cultural landscape; the person can comprehend it through senses and images and is aware of their place in the cultural landscape.

The cultural and semantic integral situation focuses on students' life comprehension of the cultural landscape. It instills in them the understanding of its importance, as well as the need to observe ethical standards for its sustainable development. Cultural and creative integral 
situation encourages students' sustainable life creation, which transforms into the cocreation with the natural world applying the ideas of coevolution.

The productive and evaluative component includes a set of criteria that represent the totality of the cognitive, value and normative, emotional and image, as well as practical components of the nature management culture. We identified the following levels of the culture of nature management that reflect the integrity and continuity of students' development of the cultural landscape: 1) the cultural and adaptation level; 2) the cultural and semantic level; and $3)$ the cultural and creative level.

In this research, the levels of the nature management culture are linked with sustainable lifestyle of students in the cultural landscape. We devised the methodology titled "Integral Project: A Journey Through the Cultural Landscape" and used it as a tool for pedagogical diagnostics of the indicated levels. This methodology became the basis for assessing the effectiveness of the pedagogical model for the development of a sustainable lifestyle of a student in a cultural landscape. We conducted the experiment in several schools in the city and in the region of Nizhny Novgorod (Russia).

At the first stage, we determined the initial level of the sustainable lifestyle of the individual in the cultural landscape. At the second stage, we applied the model proposed at geography lessons of schoolchildren aged 14-15 years old. The control stage allowed us to identify the final level, as well as the dynamics of the development of the sustainable lifestyle of a student in the cultural landscape driven by the introduced pedagogical model, which made it possible to evaluate its effectiveness

The devised methodology "Integral Project: A Journey Through the Cultural Landscape" was used as diagnostic materials. We analyzed the results (Figure 1) at the first stage and at the end of the experiment and revealed positive dynamics in the development of the sustainable lifestyle of a person in the cultural landscape. 
Figure 1 - Results of the pedagogical experiment

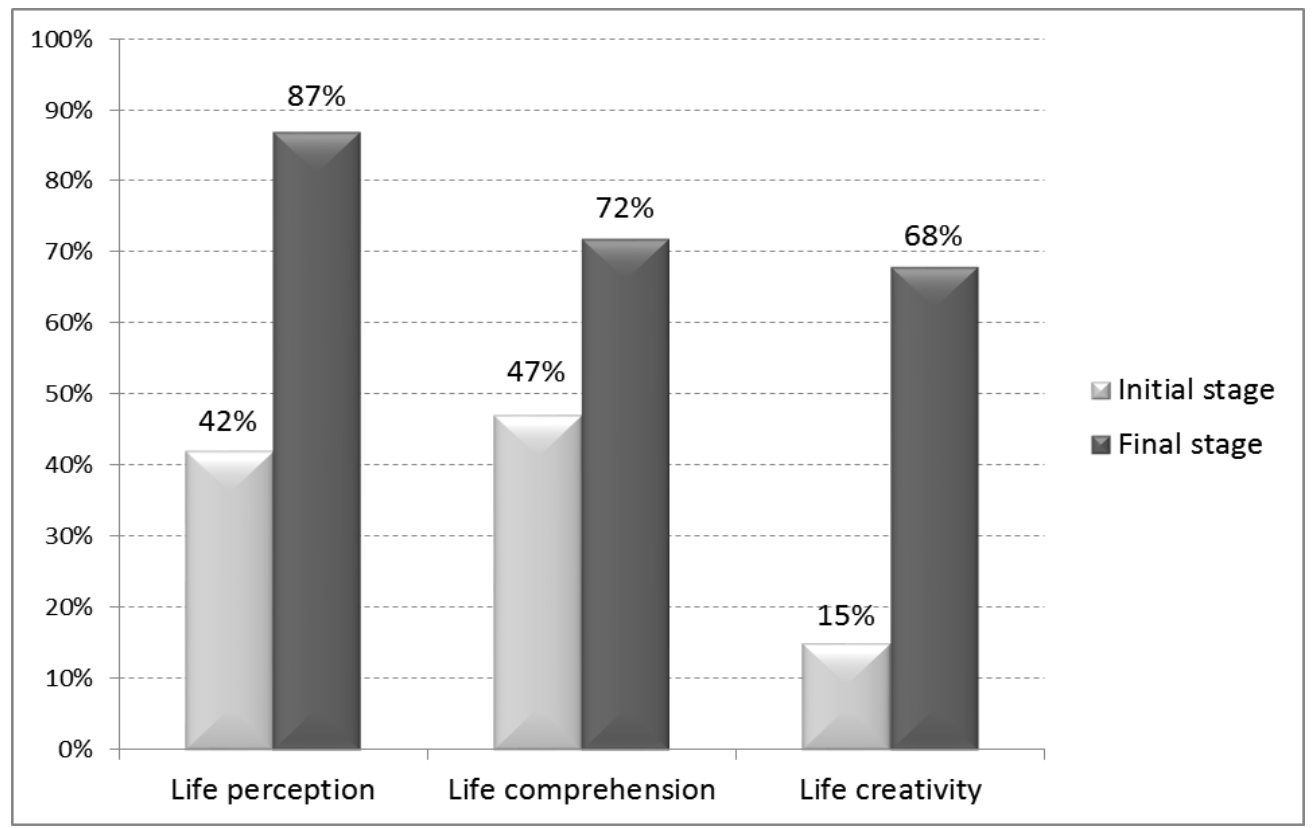

Source: Prepared by the authors

After the implementation of the project "I and the Cultural Landscape", more students fully developed the sustainable life perception ( $42 \%$ at the initial stage compared to $87 \%$ at the final stage). Similarly, $72 \%$ of the students developed sustainable life comprehension in the cultural landscape (compared to $47 \%$ at the initial stage). Having analyzed the level of the development of life creation, we found out that $68 \%$ of students fully mastered it, while at the initial stage this figure was only $15 \%$.

In general, the data obtained in the course of the pedagogical experiment confirm the effectiveness of the pedagogical model for the development of a sustainable lifestyle in the cultural landscape.

\section{Discussion}

Developing a pedagogical model for promoting a sustainable lifestyle in a cultural landscape is a significant and relevant issue in modern education as it fosters sustainable development, which is becoming an important element of the culture. This creates prerequisites for the development of a person as a subject of culture and forming an adequate lifestyle (BONDAREVSKAYA, 2014; CHUPRIKOVA, 2009; VALITSKAYA, 2009; WOODGATE; ISABWE, 2018).

Some researchers considered the cultural landscape an object of cognition. Kilper and Gailing (2019) define it as a regional space for the actions of stakeholders from various 
institutional systems that evaluate and influence its creation and development. We agree with the research results by Kerle and Fleming (2012) that there is need for two-way cooperation in the management of natural and cultural resources of the landscape. Also, it is necessary to involve the local community in its conservation and improvement by strengthening various deeply rooted cultural ties with the landscape and the holistic synthesis of scientific and traditional knowledge (KERLE; FLEMING, 2012; KILPER; GAILING, 2019). Another crucial idea for our research is the point made by Ken Nicolson about the importance of studying the dynamic interaction of human and nature in order to understand and assess the essence of the cultural landscape, as well as the close connection of cultural values with the perception, understanding, and interpretation of the cultural landscape (KERLE; FLEMING, 2012). Ilovan, Ursu and Dulama (2019) reveal the influence of visual images of cultural landscapes on learners' understanding of their essence and meaning.

According to Elsaed (2019), images of landscapes form a sense of place and identity with them, which ensures their preservation and development. Dillon (2015), Elsaed (2019) and Loi and Dillon (2006) indicated the importance of perceptual, subjective experience in solving cultural and environmental problems.

In this research, we relied on the ideas of Tyurina and Ignatova (2021), who revealed the relationship between the development of an eco-friendly personality and the formation of ecological social and natural spaces, and their mutual influence on each other. They developed criteria for assessing human influence on the formation of ecological-social-natural space.

However, there has been no comprehensive pedagogical research into the development of a sustainable lifestyle of students in a cultural landscape. The pedagogical model for the development of a sustainable lifestyle of students we devised synthesizes cultural and activity educational paradigms, which allowed us to overcome the existing gaps in the study of cultural landscapes. Within this approach, the student acts as a subject of life and culture and takes the central position in the pedagogical model. Its methods of a sustainable lifestyle represent coevolutionary guidelines for coexistence, codevelopment, and cocreation of humans and the cultural landscape surrounding them. These provisions determined the scientific novelty of the research.

The theoretical significance includes exploring the methodological foundations for the development of a sustainable lifestyle of students in the cultural landscape in line with the objective and subjective semantic universals of the nature management. The practical significance of the research is associated with the content (DEMIDOVA; VINOKUROVA, 2019) and the diagnostic method "Integral project-journey through the cultural landscape" 
(VINOKUROVA et al., 2021) we developed. The research results can be used at school lessons and in other educational institutions.

\section{Conclusions}

In this research, we created a pedagogical model for the development of a sustainable lifestyle of students in a cultural landscape. Its methodological basis is coevolutionary subject activity, transdisciplinary, integral, integral-situational, cultural-ecological, and landscapeenvironmental approaches, which reflect the cultural and civilizational development trends and modern educational paradigms. The structure of the pedagogical model implies the interconnection of interdependent components: goals, content, procedural, technological, productive, and evaluative components. These components embody the most important pedagogical ideas connected with subjectivity, axiology, creativity, and independent action.

The key vector of the model sets the goal component, which embraces the strategic goal (the formation of the culture of nature management) and the subjective goal, which implies that students become the subject of their life through the development of a sustainable lifestyle in the cultural landscape (life perception, life-comprehension, and life-creation). The dynamics of developing this lifestyle underlies the formation of the subject-subject relationship of the individual with the environment: from the isolated subject to the cooperating subject, and further-the generating subject.

The content component includes internal and external content. We selected it according to the components of the nature management culture and structured it according to the categories of "the whole" and "the part", as well as the ideas of integration and differentiation. The key object of cognition in the content is the cultural landscape, since it is human-sized, which ensures that students will develop coevolutionary values and later implement them in the constructive and creative activities in the cultural landscape.

The procedural component includes cultural-adaptive, cultural-semantic, and culturalcreative stages that reflect the process of a person's cultural development of value and semantic dominants of the cultural landscape through adaptation, comprehension, and creation. Thus, the person reaches qualitatively higher levels of constructive interaction in the cultural landscape through self-identification, self-determination, and self-realization.

The technological component of the model makes the content personally meaningful through culturally focused integral situations reflecting the development stages of the methods of a sustainable lifestyle. 
The productive and evaluative component of the model includes criteria and indicators that allow assessing the methods of a sustainable lifestyle representing the components of the nature management culture.

ACKNOWLEDGMENTS: The study was supported by a grant from the Russian Foundation for Basic Research, project No. 19-013-00749 Competition code A "Research into the theoretical foundations of the development of a sustainable lifestyle of schoolchildren in a cultural landscape". The team of authors would like to thank the teachers of the experimental sites at Nizhny Novgorod schools (Russia) - A. A. Burlak, Yu. R. Kraeva, I. M. Aminkaeva, O. V. Shilova, S. V. Ovchinnikova, and O. A. Dubnevskaya.

\section{REFERENCES}

BONDAREVSKAYA, E. V. Filosofskokonceptual'nye osnovy sistemnoj modernizacii pedagogičeskogo obrazovanija [Philosophical and conceptual foundations of the systemic modernization of pedagogical education]. Izvestija Volgogradskogo Gosudarstvennogo Pedagogičeskogo Universiteta [Journal of the Volgograd State Pedagogical University], Volgograd, v. 94, n. 9, p. 19-26, 2014.

BRANDIST, C.; TIHANOV, G. Materializing Bakhtin: The Bakhtin circle and social theory. Oxford: Macmillan, 2000. DOI: https://doi.org/10.1057/9780230501461

CHUPRIKOVA, N. I. Consciousness in the functional system of mental reflection and regulation of behavior and activity. Methodology and History of Psychology, Moscow, v. 4, n. 1, p. 113-129, 2009. Available: http://mhp-journal.ru/eng/2009_v4_n1_06. Access: 10 Oct. 2021.

CONCINA, E. Learning Outcomes for Sustainable Development. In: LEAL FILHO, W. (ed.). Encyclopedia of Sustainability in Higher Education. Cham: Springer, 2019. DOI: https://doi.org/10.1007/978-3-030-11352-0_220

DEMIDOVA, N. N.; VINOKUROVA, N. F. Designing an eco-oriented lifestyle of a student's personality in a cultural landscape: Theoretical and methodological discourse. Nizhniy Novgorod: Kirilitsa LLC, 2019.

DEMIDOVA, N. N. et al. El desarrollo de la cultura de gestión ambiental en estudiantes de secundaria en educación no formal con enfoque cultural y ecológico. Apuntes Universitarios, Lurigancho, v. 11, n. 1, p. 232-251, 2021. DOI: https://doi.org/10.17162/au.v11i1.569

DILLON, P. Education for Sustainable Development in a Cultural Ecological Frame. In: JUCKER, R.; MATHAR, R. (eds.). Schooling for Sustainable Development in Europe. Cham: Springer, 2015. p. 109-120. DOI: https://doi.org/10.1007/978-3-319-09549-3_7 
EFFENDI, T. D. Local Wisdom-based Environmental Education through Kikigaki Method: Japan Experience and Lesson for Indonesia. IOP Conference Series Earth and Environmental Science, Philadelphia, v. 239, 012038, 2019. DOI:

https://doi.org/10.1088/1755-1315/239/1/012038

ELSAED, H. I. M. Paintings of Cultural Landscapes. SSRN, Rochester, 2019. DOI: https://doi.org/10.2139/ssrn.3503691

HEIDEgGER, M. The Thing. In: Poetry, Language, Thought. New York: Harper \& Row, 1971.

ILOVAN, O.-R.; URSU, C.-D.; DULAMA, M. E. Visual imagery and learning about cultural landscapes during geography university studies. Romanian Review of Geographical Education, Romania, v. 8, n. 1, p. 64-96, 2019. DOI: https://doi.org/10.23741/RRGE120195

KAGANSKY, V. L. Kul'turnyj landšaft: Osnovnye koncepcii v Rossijskoj geografii [Cultural landscape: Basic concepts in Russian geography]. Observatorija Kul'tury [Cultural Observatory], Moscow, n. 1, p. 62-70, 2009.

KAROPA, G. Eastern European perspective: environmental education in Belarus. Environmental Education, v. 61, p. 31, 1999.

KERLE, A.; FLEMING, A. Ecological management in a cultural landscape. Ecological Management and Restoration, Woodburn, v. 13, n. 2, p. 110-111, 2012. DOI: https://doi.org/10.1111/j.1442-8903.2012.00650.x

KHUTORSKOY, A. V. Metodologija innovacionnoj praktiki v obrazovanii [Methodology of Innovative Practice in Education]. Moscow: Ridero, 2021.

KILPER, H.; GAILING, L. Cultural Landscapes. In: ORUM, A. M. (ed.). The Wiley Blackwell Encyclopedia of Urban and Regional Studies. Hoboken: John Wiley \& Sons, 2019. DOI: https://doi.org/10.1002/9781118568446.eurs0068

KOCHHAR-LINDGREN, K. Performing the New Sustainability Paradigm: The Role of Culture and Education. In: SCHWARZ-HERION, O.; OMRAN, A. (eds.). Strategies towards the New Sustainability Paradigm. Cham: Springer, 2015. p. 95-105. DOI: https://doi.org/10.1007/978-3-319-14699-7_8

LOI, D.; DILLON, P. Adaptive educational environments as creative spaces. Cambridge Journal of Education, Norwich, v. 36, n. 3, p. 363-381, 2006. DOI:

https://doi.org/10.1080/03057640600865959

LOSHCHILOVA, A. A. et al. Formation of environmental responsibility in schoolchildren in the educational space of a cultural landscape. Revista Espacios, Caracas, v. 40, n. 31, 18, 2019. Available: https://www.revistaespacios.com/a19v40n31/a19v40n31p18.pdf. Access: 7 Aug. 2021.

LOSHCHILOVA, A. A. et al. Practice-oriented educational program of activities of the children environmental association as a tool to form the seventh and eighth-graders' 
environmental responsibility. Nuances: Estudos Sobre Educacao, Presidente Prudente, v. 30, n. 1, p. 601-631, 2020. DOI: https://doi.org/10.32930/nuances.v30i1.7095

MATURANA, H. R.; VARELA, F. J. Autopoiesis and Cognition: The realization of the living. Dordrecht: Springer, 1980. https://doi.org/10.1007/978-94-009-8947-4

MOISEEV, N. N. [On worldview and world perception]. [Ecology and Life], v. 12, n. 4, p. 48, 1999. In Russian.

PANOV, V. I. Psihologičeskie aspekty èkologičeskogo obrazovanija [Psychological aspects of environmental education]. Pedagogika [Pedagogy], v. 5, p. 59-69, 2015.

PREOBRAZHENSKY, V. S. Ja - geograf: Iz tvorčeskogo nasledija [I am a geographer: From the creative legacy]. Moscow: GEOS, 2001.

RAGULINA, M. V. Kul'turnyj landšaft: Integral'nyj vzgljad [Cultural Landscape: An Integral Perspective]. Ulyanovsk: Zebra, 2015.

ROCHA, P. et al. Ecological Indigenous (EIK) and Scientific (ESK) Knowledge Integration as a Tool for Sustainable Development in Indigenous Communities. Experience in Misiones, Argentina. In: MONTAGNINI, F. (ed.). Integrating Landscapes: Agroforestry for Biodiversity Conservation and Food Sovereignty. Advances in Agroforestry. Cham: Springer, 2017. p. 235-260. DOI: https://doi.org/10.1007/978-3-319-69371-2_10

SÁNCHEZ GALERA, M. D. Conceptualising and Understanding Education and Cultural Challenges for Sustainability Transformation. Raising Awareness on the Big Picture. In: Educational and Cultural Challenges of the European Sustainability Model. Cham: Springer, 2020. p. 109-177. DOI: https://doi.org/10.1007/978-3-030-38716-7_4

STENGERS, I. Civilize modernity? Whitehead and Ruminations of Common Sense. Dijon: Les presses du reel, 2017.

TRESS, B.; TRESS, G.; FRY, G. Defining concepts and the process of knowledge production in integrative research. In: TRESS, B.; TRESS, G.; FRY, G.; OPDAM, P. (eds.). From Landscape Research to Landscape Planning: Aspects of Integration, Education and Application. Heidelberg: Springer, 2005. p. 13-26. DOI: https://doi.org/10.1007/978-1-40205363-4_2

TYURINA, T.; IGNATOVA, O. Formation of the habitat as a complex eco-social-natural space of an ecologically oriented person. In: INTERNATIONAL SCIENTIFIC AND PRACTICAL CONFERENCE "STATE AND PROSPECTS FOR THE DEVELOPMENT OF AGRIBUSINESS - INTERAGROMASH 2021”, 14., 2021, Rostov-on-Don. Proceedings [...]. Rostov-on-Don: E3S Web of Conferences, 2021. DOI: https://doi.org/10.1051/e3 sconf/202127310009

UNITED NATIONS EDUCATIONAL, SCIENTIFIC AND CULTURAL ORGANIZATION (UNESCO). Education 2030 - Incheon Declaration and Framework for Action for the implementation of Sustainable Development Goal 4: Ensure inclusive and equitable quality education and promote lifelong learning opportunities for all. 2016. Available: http://uis.unesco.org/en/document/education-2030-incheon-declaration-towards-inclusiveequitable-quality-education-and. Access: 20 July 2020. 
UNITED NATIONS EDUCATIONAL, SCIENTIFIC AND CULTURAL ORGANIZATION (UNESCO). The Hangzhou Declaration: Placing Culture at the Heart of Sustainable Development Policies. In: INTERNATIONAL CONGRESS “CULTURE: KEY TO SUSTAINABLE DEVELOPMENT”, 2013, Hangzhou. Proceedings [...]. Hangzhou: UNESCO, 2013. Available:

http://www.unesco.org/new/fileadmin/MULTIMEDIA/HQ/CLT/pdf/final_hangzhou_declarat ion_english.pdf. Access: 7 Aug. 2021.

UNITED NATIONS. General Assembly. Resolution adopted by the General Assembly on 25 September 2015. Transforming our world: the 2030 Agenda for Sustainable Development. 2015. Available:

https://www.un.org/en/development/desa/population/migration/generalassembly/docs/globalc ompact/A_RES_70_1_E.pdf. Access: 7 Aug. 2021.

VALITSKAYA, A. P. O nacional'nom tipe obrazovannosti [On the national type of education]. Vestnik Gercenovskogo Universiteta [Bulletin of the Herzen University], Saint Petersburg, v. 99, p. 87-93, 2009. Available:

https://lib.herzen.spb.ru/media/magazines/contents/1/99/valitskaya_99_87_93.pdf. Access: 8 Dec. 2021.

VAN GROENOU, W. W. Education amidst a cultural crisis phenomenology of life. In: TYMIENIECKA, A. T. (ed.). Phenomenology of Life: Meeting the Challenges of the Present-Day World. Analecta Husserliana. Dordrecht: Springer, 2005. p. 465-552. DOI: https://doi.org/10.1007/1-4020-3065-7_32

VEDENIN, Y. A. Cultural landscape as a guardian of the Ecumenic memory. Čelovek: Obraz i Suŝnost'. Gumanitarnye Aspekty [Human Being: Image and Essence. Humanitarian Aspects], Moscow, v. 36, n. 1, p. 21-37, 2019. DOI: https://doi.org/10.31249/chel/2019.01.00

VINOKUROVA, N. F. et al. Diagnósticos de desenvolvimento de métodos para a atividade de vida ecológica de um indivíduo na paisagem cultural. Laplage em Revista, Paulinia, v. 7, n. 3, p. 239-257, 2021. DOI: https://doi.org/10.24115/S2446-62202021731293p.239-257

WILBER, K. The Integral Vision: A Very Short Introduction to the Revolutionary Integral Approach to Life, God, the Universe, and Everything. Boston: Shambhala, 2007.

WOODGATE, D.; ISABWE, G. Developing future vision landscape and models of technology enhanced learning. In: INTERNATIONAL TECHNOLOGY, EDUCATION AND DEVELOPMENT CONFERENCE, 12., 2018, Valencia. Proceedings [...]. Valencia: INTED, 2018. p. 6824-6835. DOI: https://doi.org/10.21125/inted.2018.1608

ZAMYATIN, D. Storie locale e metodologie di modellizzazione della citta secondo i criteri della geografia umana. In: Dintorni. Rivista di letterature e culture dell'Universita degli Studi di Bergamo. Bergamo: Università degli Studi di Bergamo, 2008. p. 29-73. 


\section{How to reference this article}

DEMIDOVA, N. N.; LOSHCHILOVA, A. A.; VINOKUROVA, N. F.; ZULKHARNAEVA, A. V.; MARTILOVA, N. V. Pedagogical model for the development of a sustainable lifestyle of a student in a cultural landscape. Revista on line de Política e Gestão Educacional, Araraquara, v. 25, n. 3, p. 2291-2310, Sep./Dec. 2021. e-ISSN:1519-9029. DOI: https://doi.org/10.22633/rpge.v25i3.15928

Submitted: $23 / 09 / 2021$

Required revisions: $20 / 10 / 2021$

Approved: $22 / 11 / 2021$

Published: 08/12/2021 